\title{
PERMAINAN EDUKASI ULAR TANGGA MENINGKATKAN PENGETAHUAN DAN KONSUMSI SAYUR BUAH PADA REMAJA DI JAKARTA SELATAN
}

\author{
Tri Sari Wijayanti*, Adhila Fayasari, Tri Ardianti Khasanah \\ Program Studi S1 Gizi, Fakultas Kesehatan Masyarakat, Universitas Binawan \\ J1. Kalibata Raya No. 25-30, Jakarta Timur 13630, Indonesia \\ *Korespondensi : E-mail: trisariwijayanti230198@gmail.com,
}

\begin{abstract}
Background: Fruit vegetables intake recommendation is included in balanced nutrition guidelines. The average consumption of fruit vegetables for Indonesian adolescents aged $>10$ years is still low. Nutrition education is related to adolescent behavior in choosing healthy foods, especially fruit vegetables.

Objective: To analyze the effect of educational game on knowledge and consumption of fruit vegetables in adolescents at SMP Negeri 238, South Jakarta.

Methods: This study used a quasi-experimental pretest-posttest one control group design which was conducted in January-February 2020 on 50 students of SMP Negeri 238 Jakarta. Subjects were divided into 2 groups, lecture group as control and lecture-games group as intervention. The intervention was carried out for 1 month with administration once per week. The data collected in the form of characteristics and knowledge data measured using a questionnaire, and consumption of fruit vegetables measured using the SQ-FFQ. Data were analyzed by univariate analysis, and. bivariate analysis using Mann-whitney test and Wilcoxon test.

Results: There were differences in knowledge and consumption of fruit vegetables before and after intervention in both groups $(p<0.05)$. The increase in knowledge scores was significantly higher in the lecture-game group compared to those who received lectures only ( $p<0.05$; mean difference 26). There was no difference in fruit vegetable consumption increase between the lecture-game and lecture groups ( $p$ 0.554; $p$ 0.516)), but there was likely higher fruit vegetable consumption in lecture-game group.
\end{abstract}

Conclusion: Educational games can significantly increase fruit vegetables' knowledge, but not for fruit vegetable consumption in adolescents.

Keywords: educational game; knowledge; vegetable and fruit intake; adolescent

\section{ABSTRAK}

Latarbelakang: Anjuran konsumsi sayur buah termasuk dalam 10 pesan yang terdapat pada pedoman gizi seimbang. Rerata konsumsi sayur buah remaja Indonesia usia $>10$ tahun masih rendah.Edukasi gizi berkaitan dengan perilaku remaja dalam memilih makanan sehat terutama sayur buah.

Tujuan: Menganalisis pengaruh media permainan edukasi terhadap pengetahuan dan konsumsi sayur buah pada remaja di SMP Negeri 238 Jakarta Selatan.

Metode: Penelitian ini menggunakan quasi eksperimental pretest-posttest one control group design yang dilakukan pada bulan Januari-Februari 2020 pada 50 siswa SMP Negeri 238 Jakarta. Subjek dibagi menjadi 2 kelompok yaitu yang mendapatkan ceramah sebagai kontrol dan ceramah-permainan sebagai kelompok intervensi. Intervensi dilakukan selama 1 bulan dengan pemberian 1 kali per minggu. Data yang dikumpulkan berupa data karakteristik dan pengetahuan yang diukur dengan menggunakan kuesioner, dan konsumsi sayur buah yang diukur menggunakan SQ-FFQ. Data dianalisis secara univariat dan bivariat. Analisis bivariat menggunakan uji paired t-test dan independent t-test.

Hasil: Ada perbedaan pengetahuan dan konsumsi sayur buah sebelum dan sesudah diberi intervensi pada kedua kelompok $(\mathrm{p}<0,05)$. Peningkatan skor pengetahuan secara signifikan lebih tinggi pada kelompok ceramah-permainan dibandingkan dengan yang mendapatkan ceramah saja ( $<<0,05$; selisih skor 26). Tidak ada perbedaan skor peningkatan konsumsi sayur buah antara kelompok ceramah-permainan dan ceramah ( $\mathrm{p} 0,554 ; \mathrm{p} 0,516$ ), namun ada kecenderungan peningkatan skor konsumsi sayur buah lebih besar pada kelompok ceramah-permainan.

Simpulan: Permainan edukasi secara signifikan dapat meningkatkan pengetahuan mengenai sayur buah, namun tidak pada konsumsi sayur dan buah pada remaja.

Kata Kunci: permainan edukasi; pengetahuan; konsumsi sayur buah; remaja 


\section{PENDAHULUAN}

Tubuh dalam memenuhi kebutuhan harian, memerlukan asupan zat gizi yang seimbang. Anjuran konsumsi sayur buah termasuk dalam 10 pesan yang terdapat pada Pedoman Gizi Seimbang. ${ }^{1}$ Konsumsi sayur buah yang tidak memadai akan berkaitan dengan kesehatan yang buruk. Menurut World Health Organization (WHO), sebanyak 3,9 juta kematian di seluruh dunia berkaitan dengan meningkatnya resiko penyakit tidak menular akibat rendahnya konsumsi sayur buah. ${ }^{2}$

Masa remaja awal merupakan fase di mana fisik, aspek sosial maupun psikologis seseorang sedang mengalami perkembangan yang pesat. Fase ini membuat remaja ingin mengeksplorasi makanan apa saja terkait gaya hidup dan perilaku mereka. ${ }^{3}$ Laporan Riset Kesehatan Dasar (Riskesdas) tahun 2018 diketahui sebanyak $(96,8 \%)$ remaja usia 10-14 tahun masuk dalam kategori kurang konsumsi sayur buah yaitu porsi makan buah dan sayurnya $<5$ porsi per hari dalam seminggu. ${ }^{4}$ Menurut Riskesdas Provinsi DKI Jakarta tahun 2013, rerata konsumsi buah atau sayur penduduk umur 10 tahun ke atas di wilayah Jakarta Selatan menunjukkan angka konsumsi paling rendah dengan rerata sayur sebanyak 0,9 porsi/hari dan buah sebanyak 0,6 porsi/hari, sedangkan di tahun 2018 rerata konsumsi sayur meningkat menjadi 3,9 porsi/hari dan rerata konsumsi buah sebanyak 1,61 porsi/hari. ${ }^{4,5}$

Pengetahuan seseorang berkaitan dengan perilaku konsumsi sayur buah. ${ }^{6}$ Meningkatnya pengetahuan gizi akan berkaitan pula dengan meningkatnya konsumsi sayur buah pada remaja. Semakin tinggi pengetahuan gizi remaja, maka akan semakin tinggi pula tingkat konsumsi sayur buah. ${ }^{7}$ Edukasi gizi dapat dilakukan melalui penyuluhan kesehatan dengan beberapa media dan metode. Salah satu metode yang dapat dilakukan yaitu penyuluhan dengan metode ceramah. Hasil penelitian Safitri dan Fitranti tahun 2016 menyebutkan bahwa pengetahuan pada remaja overweight di kelompok ceramah mengalami peningkatan dari $72,99 \%$ menjadi $78,88 \%{ }^{8}$

Peningkatan pengetahuan dan perilaku dapat dilakukan dengan metode ceramah, maupun dengan beberapa media edukasi permainan. ${ }^{9}$ Beberapa penelitian dengan media edukasi permainan menyatakan bahwa terdapat peningkatan perilaku konsumsi pada remaja, setelah diberikan edukasi dengan permainan ular tangga sayur buah dari yang sebelumnya hanya 10 siswa $(62,5 \%)$ menjadi 14 siswa $(87,5 \%) .{ }^{9}$ Berdasarkan uraian latar belakang tersebut, maka peneliti ingin mengetahui pengaruh media permainan edukasi terhadap pengetahuan dan konsumsi sayur buah pada remaja. Penelitian ini bertujuan untuk menganalisis pengaruh media permainan edukasi ular tangga terhadap pengetahuan dan konsumsi sayur buah pada remaja di SMP Negeri 238 Jakarta Selatan.

\section{METODE}

Penelitian ini dilaksanakan bulan JanuariFebruari 2020 pada siswa SMP Negeri 238 Jakarta. Penelitian menggunakan desain eksperimen semu (quasi eksperimental) dengan rancangan pretestposttest one control group design. Kriteria inklusi dalam penelitian ini antara lain siswa kelas VII yang berstatus aktif dan terdaftar di SMP Negeri 238 Jakarta, bersedia menjadi sampel dan hadir selama 4 kali pertemuan. Adapun kriteria eksklusinya yaitu siswa yang tidak hadir minimal 1 kali selama penelitian.Teknik pengambilan sampel yang digunakan yaitu purposive sampling. Dari 72 siswa, didapatkan 50 siswa yang memenuhi kriteria, sebanyak 12 siswa tidak mengikuti penelitian karena tidak hadir dan sakit. Subyek dibagi menjadi 2 kelompok yaitu kelompok kontrol (ceramah) dan kelompok intervensi (ceramah-permainan) masingmasing sebanyak 25 subjek. Pengelompokan dilakukan secara purposive oleh pihak sekolah.

Data yang diambil antara lain data karakteristik subjek (jenis kelamin, usia, tingkat ekonomi keluarga, keterpaparan media massa dan tingkat perubahan perilaku atau stages of change), pengetahuan dan konsumsi sayur buah. Data karakteristik diperoleh melalui pengisian kuesioner.

Data mengenai tahapan perubahan (stages of changes) inidiukur dengan menggunakan kuesioner yang terdiri dari 2 pertanyaan skala guttman yaitu 1) Apakah Anda mengonsumsi berbagai macam sayur atau buah? 2) Apakah Anda berniat untuk mengonsumsi berbagai macam sayur/buah ? Jika menjawab Ya saya sudah mengonsumsi berbagai sayur/buah sejak saya kecil, pada pertanyaan pertama maka termasuk kedalam kategori 'maintenance', jika menjawab Ya, saya mulai mengonsumsi berbagai macam sayur/buah dalam waktu 6 bulan terakhir, maka termasuk kedalam kategori 'action'. Jika menjawab 'tidak' pada pertanyaan pertama, maka lanjut ke pertanyaan kedua. Jika pada pertanyaan kedua menjawab Ya, saya akan mengonsumsi berbagai macam sayur/buah dalam 1 atau 2 bulan, maka termasuk kategori 'preparation', jika menjawab Tidak, tetapi saya berencana akan mengonsumsi berbagai macam sayur buah mendatang, maka termasuk kategori contemplation, dan jika menjawab tidak, saya tidak bermaksud untuk mengonsumsi berbagai macam sayur/buah, maka termasuk kategori 'precontemplation'11

Data pengetahuan diperoleh melalui kuesioner mengenai sayur buah sebanyak 20 pertanyaan, dengan hasil uji validitas nilai rata-rata $r$ hitung 1,956 dan uji realibilitas didapatkan nilai Alpha Cronbach 
sebesar 0,617 . Pertanyaan yang ditanyakan mengenai kandungan gizi sayur buah, kandungan non gizi sayur buah, manfaat sayur buah, cara mengolah sayuran dan anjuran konsumsi sayur buah. Konsumsi sayur buah diukur dengan menggunakan $S Q-F F Q$ yang berisi daftar sayur buah sebanyak 30 item. Daftar sayur buah dimodifikasi dari penelitian Farisa tahun 2012 disesuaikan dengan hasil food recall penelitian pendahuluan pada siswa SMP. ${ }^{6}$ Jika item sayur buah ditemukan dalam hasil food recall dan SQ-FFQ minimal oleh 1 subyek, maka item sayur buah tersebut dimasukan ke dalam kuesioner SQ-FFQ.

Permainan ular tangga sayur buah (Utasabu) ini menggunakan karpet besar berukuran berukuran $3 \times 2$ meter berbentuk angka 8 terdiri dari 18 kotak, terdapat 2 ular dan 2 tangga dalam papan permainan ini. Alat-alat pendukung permainan antara lain ikat kepala dari pita, dadu berbentuk bantal, dan kartu pertanyaan sebanyak 20 buah berisikan materi sayur buah. Permainan ini berdurasi 20 menit dengan melibatkan 2 tim yang terdiri 2-3 siswa sebagai bidak. Setiap kotak siswa diharuskan menjawab pertanyaan terkait konsumsi sayur buah, jika jawaban salah, maka bidak harus mundur. Pemain dinyatakan menang jika telah melewati satu putaran permainan atau kembali pada kotak start. Permainan ini telah diujicobakan pada 6 orang siswa SMP. Hasil mendapatkan bahwa permainan ini cukup menarik dan pertanyaan sayur buah yang terdapat pada kartu permainan dapat dijawab.

Penelitian ini dilakukan selama 4 minggu, intervensi dilakukan sebanyak 2 kali pertemuan, tiap seminggu sekali dimulai dari minggu kedua. Kuesioner pengetahuan diberikan pada awal dan akhir intervensi. Di tiap sesi permainan diberikan post-test pengetahuan, dan post-test SQ-FFQ diberikan 1 minggu setelah intervensi terakhir.

Analisis data dilakukan secara univariat dan bivariat. Analisis univariat disajikan dalam bentuk persentase dan rata-rata. Analisis bivariat menggunakan uji beda, jika data terdistribusi normal maka menggunakan analisis parametrik, sebaliknya jika data tidak terdistribusi normal maka menggunakan uji non parametrik. Tingkat kesalahan yang digunakan adalah 5\%. Uji paired t-test atau Wilcoxon test dilakukan untuk mengetahui perbedaan skor sebelum dan sesudah intervensi. Uji independent t-test atau Mann-Whitney dilakukan untuk mengetahui perbedaan peningkatan skor antara kelompok intervensi dan kontrol. Penelitian ini telah disetujui oleh Komisi Etik Penelitian Kesehatan Universitas Pembangunan Nasional "Veteran" Jakarta dengan nomor B/2227/XII/2019/KEPK.

\section{HASIL}

Subjek pada penelitian ini, rata-rata berusia 12 tahun, proporsi laki-laki dan perempuan kurang lebih sama. Tingkat ekonomi keluarga pada penelitian ini sebagian besar dibawah UMR (Upah Minimum Regional sebesar 4.200.000), yaitu sebanyak (90\%). Berdasarkan Tabel 1, secara keseluruhan sudah pernah terpapar informasi mengenai sayur buah dengan mayoritas mendapat informasi melalui media internet sebanyak (56\%) sisanya mendapatkan informasi melalui televisi, maupun media billboard.

Tahapan perubahan (stages of changes) terbagi menjadi precontemplation, contemplation, preparation, action dan maintenance. Tahapan tertinggi dari suatu perilaku adalah maintenance, bahwa konsumsi sayur buah sudah menjadi kebiasaan yang dilakukan sehari-hari. ${ }^{10}$ Berdasarkan tabel 1, sebagian besar subjek berada pada tingkat maintenance pada kelompok ceramah permaianan dibandingkan dengan kelompok ceramah (72\% dan $32 \%$ ), sedangkan pada kelompok ceramah cenderung lebih banyak pada tahapan action dan maintenance yaitu masing-masing sebanyak 32\%. Setelah intervensi, peningkatan lebih banyak pada kelompok ceramah, dari sebelumnya subjek pada tahapan maintenance sebanyak $32 \%$ meningkat menjadi $80 \%$, sedangkan pada kelompok ceramah permainan, ada penurunan tahapan maintenance menjadi $68 \%$ dari $72 \%$.

Tabel 2 menunjukan rerata frekuensi sayur buah paling banyak dikonsumsi oleh remaja. Lima jenis sayur yang paling banyak dikonsumsi adalah wortel, bayam, kangkung, jamur dan buncis. Wortel merupakan jenis sayur yang paling banyak dikonsumsi dengan rerata frekuensi sebesar 0,83 per minggu. Sedangkan, 5 jenis buah yang paling banyak dikonsumsi adalah mangga, jeruk, alpukat, pepaya dan semangka. Mayoritas subjek mengonsumsi mangga dengan rerata frekuensi sebesar 0,51 per minggu.

Terdapat perbedaan rerata yang bermakna pada kedua kelompok baik pada kelompok ceramah ( $\mathrm{p}$ $0,001)$ dan pada kelompok ceramah-permainan ( $p$ $<0,001$ ) (Tabel 3). Hal ini berarti terdapat perubahan pengetahuan pada kedua kelompok sebelum dan setelah diberikan intervensi. Peningkatan skor pengetahuan secara signifikan lebih tinggi pada kelompok ceramah-permainan dari pada kelompok ceramah ( $\mathrm{p}<0,001)$, dengan nilai 22,6 lebih tinggi.

Berdasarkan analisis pada konsumsi sayur menunjukkan bahwa terdapat perubahan konsumsi sayur pada kelompok ceramah (p 0,020), namun tidak terdapat perubahan konsumsi sayur pada kelompok ceramah-permainan (p 0,116) sebelum dan setelah diberikan intervensi. Selain itu, pada 
hasil uji statistik Mann Whitney diketahui tidak terdapat perbedaan yang signifikan antara penggunaan metode ceramah dengan metode ceramah-permainan untuk meningkatkan konsumsi sayur dengan nilai (p 0,9). Namun, terdapat kecenderungan konsumsi sayur pada kelompok ceramah-permainan sedikit lebih besar daripada kelompok ceramah $(29,4 \mathrm{~g}$ dan 23,09 g). Hal ini dimungkingkan bahwa konsumsi sayur awal pada kelompok ceramah-permainan sudah lebih besar daripada kelompok ceramah, sehingga peningkatannya tidak terlalu besar dan signifikan dibandingkan kelompok ceramah.

Berdasarkan analisis pada konsumsi buah diketahui tidak terdapat perubahan signifikan pada konsumsi buah di kedua kelompok ( $p>0,05)$ sebelum maupun setelah diberikan intervensi masing-masing. Hasil uji statistik Mann Whitney menunjukkan bahwa terdapat perbedaan skor peningkatan konsumsi buah yang signifikan antara penggunaan metode ceramah dengan metode ceramah-permainan (p 0,019).

Tabel 1. Karakteristik Subjek

\begin{tabular}{lcccc}
\hline Karakteristik Subjek & \multicolumn{2}{c}{ Ceramah } & \multicolumn{2}{c}{ Ceramah-Permainan } \\
\cline { 2 - 5 } & $\mathbf{n}$ & $\mathbf{( \% )}$ & $\mathbf{n}$ & $\mathbf{( \% )}$ \\
\hline Usia & & & & \\
$\quad 12$ tahun & 13 & 52,0 & 13 & 52,0 \\
$\quad 13$ tahun & 12 & 48,0 & 12 & 48,0 \\
$\quad$ Jenis Kelamin & & & & \\
$\quad$ Laki-laki & 12 & 48,0 & 12 & 48,0 \\
$\quad$ Perempuan & 13 & 52,0 & 13 & 52,0 \\
Tingkat Ekonomi Keluarga & & & & \\
$\quad$ UMR & 21 & 84,0 & 24 & 96,0 \\
$\quad$ UMR & 4 & 16,0 & 1 & 4,0 \\
Keterpaparan Media Massa & & & & \\
$\quad$ Televisi & 10 & 40,0 & 5 & 20,0 \\
$\quad$ Televisi, Internet & 4 & 16,0 & 2 & 8,0 \\
$\quad$ Internet & 11 & 44,0 & 17 & 68,0 \\
$\quad$ Internet, Media Billboard & 0 & 0,0 & 1 & 4,0 \\
Tingkatan Perubahan Perilaku (sebelum intervensi) & & & & \\
$\quad$ Precontemplation & 3 & 12,0 & 2 & 8,0 \\
$\quad$ Contemplation & 6 & 24,0 & 0 & 0,0 \\
$\quad$ Action & 8 & 32,0 & 5 & 20,0 \\
$\quad$ Maintenance & 8 & 32,0 & 18 & 72,0 \\
Tingkatan Perubahan Perilaku (setelah intervensi) & & & 4,0 \\
$\quad$ Precontemplation & 1 & 4,0 & 1 & 12,0 \\
$\quad$ Contemplation & 1 & 4,0 & 3 & 16,0 \\
$\quad$ Action & 3 & 12,0 & 4 & 68,0 \\
$\quad$ Maintenance & 20 & 80,0 & 17 &
\end{tabular}

Tabel 2. Frekuensi Sayur Buah Paling Banyak Dikonsumsi

\begin{tabular}{lclc}
\hline \multicolumn{1}{c}{ Jenis Sayur } & $\begin{array}{c}\text { Frekuensi Konsumsi } \\
\text { Sayur (per minggu) }\end{array}$ & \multicolumn{1}{c}{ Jenis Buah } & $\begin{array}{c}\text { Frekuensi Konsumsi Buah } \\
\text { (per minggu) }\end{array}$ \\
\hline Wortel & 0,83 & Mangga & 0,51 \\
Bayam & 0,61 & Jeruk & 0,50 \\
Kangkung & 0,52 & Alpukat & 0,31 \\
Jamur & 0,41 & Pepaya & 0,29 \\
Buncis & 0,37 & Semangka & 0,27 \\
\hline
\end{tabular}

\section{PEMBAHASAN}

Permainan edukasi menjadi alternatif bentuk edukasi yang diberikan pada anak-anak maupun remaja dengan tujuan agar lebih mudah dalam peningkatan minat dan informasi yang akan diberikan. Permainan edukasi ini merupakan media visual yang memiliki kelebihan dibandingkan media

visual yang lainnya karena melibatkan pemain secara langsung dalam menentukan hasil akhir dari game yang dimainkan. ${ }^{11}$ Adapun macam-macam permainan edukasi yang ada antara lain kartu kuartet, menggunakan kartu sebagai media tulisan dan gambar dalam memberikan informasi, permainan 
monopoli, yang menyajikan wahana untuk transfer ilmu dan memberikan pengalaman baru, kemudian ada permainan ular tangga, menyajikan permainan dan pembelajaran secara bersamaan. ${ }^{12,13,14,15}$

Permainan edukasi yang dilakukan pada penelitian ini menggunakan bentuk ular tangga yang dimodifikasi. Alur permainan menjadi lebih singkat dan isi dari pertanyaan-pertanyaan yang diajukan juga lebih padat. Adapun materi dibagi menjadi 2 topik besar yaitu mengenai kandungan gizi sayurbuah dan anjuran konsumsi serta cara penyimpanan dan pengolahan sayur buah. Intervensi diberikan sebanyak 2 kali dalam sebelum. Intervensi dalam penelitian ini menggunakan kombinasi antara ceramah dan permainan.

Tabel 3. Analisis Skor Pengetahuan, Konsumsi Sayur dan Konsumsi Buah Sebelum dan Sesudah Intervensi

\begin{tabular}{|c|c|c|c|}
\hline \multirow[t]{2}{*}{ Variabel } & \multicolumn{2}{|c|}{ Mean \pm SD } & \multirow{2}{*}{ p-value } \\
\hline & Ceramah & Ceramah-Permainan & \\
\hline \multicolumn{4}{|l|}{ Pengetahuan } \\
\hline Pre-test & $57,6 \pm 11,004$ & $47,6 \pm 10,81$ & \multirow{4}{*}{$<0,001^{\mathrm{c}^{*}}$} \\
\hline Post-test & $69,8 \pm 12,46$ & $82,4 \pm 10,22$ & \\
\hline Selisih & 12,2 & 34,8 & \\
\hline p-value & $0,001^{\mathrm{a}^{*}}$ & $<0,001^{\mathrm{b}^{*}}$ & \\
\hline \multicolumn{4}{|l|}{ Sayur (g) } \\
\hline Pre-test & $25,4 \pm 18,71$ & $32,3 \pm 27,95$ & \multirow{4}{*}{$0,516^{\mathrm{c}^{*}}$} \\
\hline Post-test & $48,49 \pm 49,45$ & $61,7 \pm 87,1$ & \\
\hline Selisih & 23,09 & 29,4 & \\
\hline$p$-value & $0,020^{\mathrm{a}^{*}}$ & $0,116^{\mathrm{a}^{*}}$ & \\
\hline \multicolumn{4}{|l|}{ Buah (g) } \\
\hline Pre-test & $115,8 \pm 101,3$ & $114,9 \pm 123,9$ & \multirow{4}{*}{$0,554^{\mathrm{c}^{*}}$} \\
\hline Post-test & $116,9 \pm 139,5$ & $125,2 \pm 113,6$ & \\
\hline Selisih & 1,1 & 10,3 & \\
\hline$p$-value & $0,951^{\mathrm{a}^{*}}$ & $0,737^{a^{*}}$ & \\
\hline
\end{tabular}

Penelitian ini menunjukan ada peningkatan skor pengetahuan secara signifikan lebih tinggi pada kelompok yang mendapatkan ceramah-permainan dibandingkan dengan kelompok ceramah $(p>0,05)$. Penelitian ini sejalan dengan penelitian Handayani di Sumatera Utara, bahwa permainan ular tangga modifikasi memberikan respon positif pada siswa MTs. ${ }^{9}$

Permainan ular tangga dapat menciptakan suasana belajar yang menyenangkan. Pengetahuan remaja dapat meningkat karena bentuk edukasi yang diberikan berupa kegiatan bermain sambal belajar yang menyenangkan, menarik, dan dapat meningkatkan sosialisasi yang baik antarsiswa. ${ }^{16}$ Permainan ular tangga menstimulasi aspek perkembangan kognitif siswa dan merangsang siswa untuk belajar memecahkan masalah tanpa disadari. Selain itu, permainan edukasi ini memiliki kelebihan dibandingkan media lainnya karena melibatkan pemain secara langsung. ${ }^{17}$

Permainan ular tangga edukatif ini sangat cepat untuk subjek mengingat materi penyuluhan yang disampaikan. Perbandingan antara permainan ular tangga dengan animasi kartun didapatkan bahwa tingkat penerimaan yang disampaikan dari animasi kartun dapat berbeda-beda tergantung dari kemampuan penyerapan informasi. Dalam penelitian oleh Laili tahun 2019 di Padang didapatkan bahwa permainan ular tangga lebih disukai dari pada animasi kartun. ${ }^{18}$
Berdasarkan analisis soal/item soal pengetahuan, topik yang menjadi benar setelah diberikan intervensi antara lain materi mengenai anjuran konsumsi sayur buah. Hasil post-test menunjukkan terdapat peningkatan sebanyak 34 subjek $(68,0 \%)$ yang dapat menjawab pertanyaan dengan benar setelah diberikan intervensi. Sementara, topik yang masih banyak salah antara lain mengenai kandungan gizi sayur buah. Pada topik ini hanya terdapat peningkatan sebesar 9 subjek $(18,0 \%)$ yang dapat menjawab pertanyaan dengan benar.

Menurut Notoatmodjo, dalam proses pendidikan dalam hal ini yang diinginkan adalah transfer ilmu, ada beberapa faktor yang mempengaruhi antara lain yaitu faktor masukan (input) dan keluaran (output), faktor metode, faktor materi atau pesannya, pendidikan atau petugas yang melakukannya, dan alat-alat bantu atau media yang digunakan untuk menyampaikan pesan. ${ }^{19}$

Penelitian ini menggabungkan metode ceramah dengan metode permainan karena pada metode permainan saja, siswa tidak cukup untuk memberikan penjelasan mengenai informasi yang akan disampaikan. Hal ini berdasarkan hasil uji pendahuluan yang telah dilakukan oleh peneliti. Penggabungan beberapa metode dan media dengan memperhatikan karakteristik subjek diharapkan dapat mendukung peningkatan pengetahuan siswa semakin baik. $^{20}$ 
Pada variabel konsumsi sayur dan konsumsi buah, kedua metode tidak signifikan meningkatkan konsumsi sayur dan konsumsi buah pada kedua kelompok $(p>0,05)$, kecuali pada konsumsi sayur di kelompok ceramah. Tidak ada perbedaan signifikan pada selisih peningkatan skor konsumsi sayur antara kelompok ceramah dan ceramah-periaman, namun, terdapat kecenderungan konsumsi sayur pada kelompok ceramah-permainan sedikit lebih besar daripada kelompok ceramah (29,4 g dan 23,09 g). Hal ini dimungkinkan bahwa konsumsi sayur awal pada kelompok ceramah-permainan sudah lebih besar daripada kelompok ceramah, sehingga peningkatannya tidak terlalu besar dan signifikan dibandingkan kelompok ceramah.

Pada variabel konsumsi buah, tidak ada perbedaan signifikan konsumsi buah sebelum dan sesudah diberikan intervensi pada kedua kelompok ( $>0,05)$, begitu pula pada perbedaan skor peningkatan konsumsi buah antara kedua kelompok ( $>0,05$ ), walaupun skor konsumsi buah lebih besar pada kelompok ceramah-permainan $(10,3 \mathrm{~g}$ dan 1,1 g). Rerata konsumsi sayur subjek setelah diberi intervensi meningkat menjadi $61,7 \mathrm{~g}$ dan $48,49 \mathrm{~g}$ per hari. Rerata ini masih dibawah dari rekomendasi WHO sebesar 250 g. $^{2}$ Begitupula konsumsi buah pada siswa masih kurang dari rekomendasi WHO sebesar $150 \mathrm{~g}$ dengan rata-rata konsumsi sebesar $125,2 \mathrm{~g}$ dan $116,9 \mathrm{~g}$ per hari setelah intervensi. ${ }^{2}$

Dari segi frekuensi, frekuensi konsumsi sayur siswa terbanyak yaitu wortel dengan rata-rata 0,83 kali dalam seminggu dan frekuensi buah terbanyak yaitu manga dengan rata-rata 0,51 . Jika dibandingkan dengan anjuran Riskesdas tahun 2013 dalam seminggu setidaknya remaja harus mengkonsumsi sayur buah 5 porsi perhari dalam seminggu. ${ }^{4}$ Baik dari segi jumlah dan konsumsi sangat kurang. Hal ini dapat berakibat meningkatnya risiko penyakit kardiovaskular dan degeneratif di kemudian hari. Sayur buah mengandung vitamin, mineral dan polifenol yang dapat memperbaiki profil lemak dan menurunkan tekanan darah. ${ }^{21,22}$ Beberapa penelitian menggunakan berbagai metode edukasi terbukti belum tentu dapat meningkatkan konsumsi secara signifikan. Edukasi dengan media audio visual menunjukan adanya peningkatan sayur buah, namun tidak signifikan dibandingkan dengan kontrol. ${ }^{23}$ Penelitian dengan leaflet dan buku saku pun menunjukan hal yang serupa. ${ }^{18}$ Menurut hasil review oleh Maranata dan Widyatuti terkait dengan efek edukasi permainan terhadap konsumsi sayur buah pada anak usia sekolah dasar didapatkan hasil bahwa permainan dapat meningkatkan konsumsi sayur dan buah, karena permainan membentuk aspek kognitif, sosial dan emosional. ${ }^{24}$

Selisih peningkatan konsumsi buah tidak signifikan, namun terdapat peningkatan lebih besar pada kelompok ceramah-permainan daripada kelompok ceramah. Hal ini karena konsumsi sayur buah remaja bergantung pada faktor internal (jenis kelamin, pengetahuan dan preferensi sayur buah) yang dapat dibentuk melalui konsumsi sayur buah secara berulang serta didukung oleh pengetahuan remaja dan daya beli keluarga dalam menyediakan sayur buah di rumah. ${ }^{25}$

Kebiasaan konsumsi remaja masih dipengaruhi oleh lingkungan keluarga. Adapun faktor lain dari konsumsi sayur buah yang masih belum sesuai dengan anjuran WHO dikarenakan faktor dari lingkungan keluarga, seperti daya beli dan ketersediaan sayur buah di rumah. Daya beli dalam menyediakan sayur buah di rumah berkaitan dengan faktor ekonomi keluarga. Tingkat ekonomi keluarga pada penelitian ini mayoritas berada di bawah UMR dengan tingkat ekonomi kelompok kontrol lebih tinggi daripada kelompok intervensi. Hal ini bisa menjadi salah satu sebab peningkatan konsumsi buah pada kelompok kontrol lebih baik daripada kelompok intervensi. Hasil penelitian di Bogor pada anak sekolah didapatkan hasil bahwa pendapatan keluarga berhubungan dengan konsumsi sayur buah. Semakin rendah pendapatan keluarga, maka mempengaruhi kemampuan keluarga tersebut dalam menyediakan makanan termasuk sayur buah. ${ }^{26}$

Dilihat dari waktu pemberian intervensi, penelitian ini dilakukan selama sebulan. Hasil dari penelitian menunjukkan bahwa terdapat peningkatan skor konsumsi sayur sebesar 29,4 g dan buah sebesar 10,3 g, namun tidak signifikan dibandingkan kontrol. Tidak adanya perubahan yang signifikan antara metode ceramah dan metode ceramah-permainan dikarenakan durasi pemberian intervensi. Dalam mengadopsi perubahan suatu perilaku, seseorang membutuhkan waktu yang relatif lama. Berdasarkan hasil penelitian review mengenai pengaruh edukasi permainan terhadap konsumsi sayur buah minimal membutuhkan waktu 8 minggu hingga 10 minggu. Secara teori, dibutuhkan tiga tahap untuk seseorang dalam mengadopsi perilaku baru yaitu dimulai dari munculnya pengetahuan, kemudian timbul sikap dan terbentuklah tindakan atau praktik. ${ }^{27}$

Jika kita dari segi tahapan perubahan perilaku, subjek dalam penelitian ini sebagian besar telah mencapai tahapan maintenance, $32 \%$ pada kelompok ceramah dan $72 \%$ pada kelompok ceramah 
permainan. Yang dapat diartikan kebiasaan konsumsi sayur buah sudah berjalan menjadi suatu kebiasaan. Pada awal intervensi, ada ketimpangan proporsi kategori maintenance antara kelompok ceramah dan kelompok ceramah permainan, yang dimana kelompok permainan lebih banyak subjek yang berada ditahap maintenance. Hal ini dapat dilihat dari segi pengetahuan, dan konsumsi sayur buah pada awal penelitian cenderung lebih tinggi pada kelompok ceramah-permainan. Setelah intervensi, peningkatan lebih banyak pada kelompok ceramah, daripada sebelumnya subjek pada tahapan maintenance sebanyak $32 \%$ meningkat menjadi $80 \%$, sedangkan pada kelompok ceramah permainan, ada penurunan tahapan maintenance menjadi $68 \%$ dari $72 \%$.

Kebiasaan yang sudah dijalani, kemudian diberi paparan mengenai hal yang sama akan memberikan 2 efek yang saling bertolak belakang, diterima atau ditolak. Hal ini dilihat dari hasil penurunan yang sebelumnya di tahap maintenance, menurun menjadi tahapan action dan contemplation, serta peningkatan konsumsi sayur buah yang tidak signifikan. Berbeda dengan yang memang belum ada pengetahuan sama sekali kemudian diberi paparan mengenai hal yang baru, akan mengalami peningkatan baik dari segi pengetahuan dan konsumsi sayur/buah, serta pada kategori tahapan maintenance (80\%) setelah diberikan intervensi.

Secara keseluruhan, pemberian metode edukasi dalam bentuk permainan memberikan bentuk positif dalam meningkatkan pengetahuan dan perilaku konsumsi, namun perlu diperhatikan dari segi internal seperti faktor ekonomi sosial dan lingkungan serta durasi pemberian dalam edukasi permainan perlu diberikan dalam jangka yang lebih panjang, karena durasi 3-4 minggu belum cukup untuk memberikan pengaruh signifikan pada perilaku.

\section{SIMPULAN}

Edukasi dengan permainan ular tangga sayur buah secara efektif dapat meningkatkan pengetahuan mengetahui konsumsi sayur buah, namun tidak pada konsumsi sayur buah, walaupun ada kecenderungan konsumsi sayur buah lebih tinggi pada kelompok edukasi permainan dibandingkan dengan kelompok ceramah. Berdasarkan hasil penelitian ini didapatkan bahwa kebiasaan konsumsi sayur buah pada remaja sudah baik, hanya saja masih belum sesuai dengan rekomendasi dari WHO. Perlu dilakukan edukasi lebih lanjut, dan permainan ular tangga dapat dipertimbangkan sebagai media yang bisa digunakan dalam pemberian edukasi. Pemberian edukasi permaian dapat menjadi alternatif media pendidikan terutama bagi anak-anak dan remaja, karena langkah awal untuk meningkatkan pemahaman akan suatu informasi dibutuhkan ketertarikan terlebih dahulu, dan hal ini dapat dimunculkan dengan permainan edukasi.

\section{UCAPAN TERIMA KASIH}

Terimakasih saya ucapkan kepada pihak SMP Negeri 238 Jakarta yang telah berpartisipasi dalam penelitian ini.

\section{DAFTAR PUSTAKA}

1. Kementerian Kesehatan RI. Peraturan Menteri Kesehatan Republik Indonesia Nomor 41 Tahun 2014 Tentang Pedoman Gizi Seimbang. Jakarta: Kementerian Kesehatan. 2014.

2. WHO. E-Library of Evidence for Nutrition Actions (eLENA): Increasing fruit and vegetable consumption to reduce the risk of noncommunicable diseases. Geneva: WHO. 2019.

3. Aryani DD. Hubungan peran teman sebaya dengan perilaku konsumsi buah dan sayur pada remaja awal di SMP Negeri 1 Nglipar Gunungkidul Yogyakarta. Yogyakarta: STIkes Jenderal Achmad Yani. Skripsi. 2016.

4. Balitbang Kemenkes RI. Riset Kesehatan Dasar: RISKESDAS. Jakarta: Balitbang Kemenkes RI. 2018.

5. Balitbang Kemenkes RI. Riset Kesehatan Dasar: RISKESDAS. Jakarta: Balitbang Kemenkes RI. 2013.

6. Farisa S. Hubungan sikap, pengetahuan, ketersediaan dan keterpaparan media massa dengan konsumsi buah dan sayur pada siswa SMPN 8 Depok Tahun 2012. Depok: FKM UI. Skripsi. 2012.

7. Rachman BN, Mustika IG, Kusumawati IGAW. Faktor yang berhubungan dengan perilaku konsumsi buah dan sayur siswa SMP di Denpasar. Jurnal Gizi Indonesia (The Indonesian Journal of Nutrition). 2017; 6(1): 9-16.

8. Safitri NRD, Fitranti DY. Pengaruh edukasi gizi dengan ceramah dan booklet terhadap peningkatan pengetahuan dan sikap gizi remaja overweight. Journal of Nutrition College. 2016; 5(4): 374-380. 
9. Azizaah DL, Arief YS, Krisnana I. Media ceramah dan film pendek sebagai upaya pencegahan penyakit diare berdasar teori health promotion model (HPM). Jurnal Pediomaternal. 2015; 3(1): 43-57.

10. Handayani I, Lubis Z, Aritonang EY. Pengaruh penyuluhan dengan media permainan ular tangga terhadap pengetahuan tentang buah dan sayur pada siswa MTs-S Almanar Kecamatan Hamparan Perak. JUMANTIK. 2017; 3(1).

11. Woo, T dan Lee, KH. Faktors affecting vegetable preference in adolescents: stages of change and social cognitive theory. Nutrition Research and Practice. 2017; 11(4): 340-346.

12. Rahman, R.A dan Tresnawati, D. Pengembangan game edukasi pengenalan nama hewan dan habitatnya dalam 3 bahasa sebagai media pembelajaran berbasis multimedia. Jurnal Algoritma: Sekolah Tinggi Teknologi Garut. 2016;13: 184-190.

13. Fatimah, AS. Efektivitas penyuluhan gizi menggunakan media PSG cards dibandingkan leaflet terhadap peningkatan pengetahuan pedoman gizi seimbang pada siswa sekolah dasar. Naskah Publikasi Prodi Gizi: Poltekkes Kemenkes Yogyakarta; 2017.

14. Marini, A., Wirapuspita, R., Iriyani, K. 2015. Pengaruh permainan monopoli dalam peningkatan pengetahuan, sikap, dan tindakan pola konsumsi buah dan sayur pada siswa SDN 021 Sungai Kunjang Samarinda. Higiene. 2015; 1(3): 155-161.

15. Nachiappan, S., Rahman, N.A., Andi, H., Zulkafaly, F.M. 2014. Snake and ladder games in cognition development on students with learning difficulties. review of arts and humanities. 2014; 3(2): 217-229.

16. Siyam SNL, Nurhapsari A, Benyamin B. Pengaruh stimulasi permainan ular tangga tentang gingivitis terhadap pengetahuan anak usia 8-11 tahun. ODONTO Dental Journal. 2015; 2(1): 25-28.

17. Putri SR, Siagian A, Sudaryati E. Pengaruh permainan monopoli gizi (monogi) tentang pola makan seimbang terhadap pengetahuan dan sikap siswa SDN 060902 Mangubumi Kota Medan Tahun 2016. Jurnal Gizi, Kesehatan Reproduksi dan Epidemiologi USU. 2016; 1(2): 1-7.

18. Laili RP. Pengaruh penyuluhan melalui media animasi kartun dan ular tangga edukatif terhadap peningkatan pengetahuan, sikap, dan tindakan konsumsi sayur dan buah pada siswa SDN 136/III Koto Tengah Kerinci. Program Studi Gizi Sekolah Ilmu Kesehatan Perintis Padang. Skripsi. 2019.

19. Notoatmodjo, S. Ilmu Kesehatan Masyarakat: Prinsip-Prinsip Dasar. Jakarta: Rineka Cipta. 2003.

20. Dhian A. Pengaruh pendidikan kesehatan melalui metode ceramah dengan audi-visual terhadap pengetahuan ibu tentang menopouse di Dukuh Girimulyo, Kelurahan Gergunung, Kecamatan Klaten Utara. Jurnal Keperawatan. 2011.

21. Dhandevi PEM, Rajesh Jeewon. Fruit and vegetable intake: benefits and progress of nutrition education interventions- narrative review article. Iran J Public Health. 2015; 44(10): 1309-1321.

22. Habauzit V, Milenkovic D, Morand C. Vascular Protective Effects of Fruit Polyphenols. In. Polyphenols in Human Health and Disease. Eds, Watson R, Preedy V, Zibadi S. 1st ed. London: Elsevier Inc. 2013. p. $875-893$.

23. Sekti RM, Fayasari A. Edukasi gizi dengan media audiovisual terhadap pola konsumsi sayur buah pada remaja SMP di Jakarta Timur. Jurnal Ilmiah Kesehatan (JIKA). 2019; 1(2): 77-88

24. Maranata R, Widyatuti, Efektifitas intervensi bermain terhadap konsumsi sayur dan buah pada anak usia sekolah dasar. Jurnal Ilmiah Permas: Jurnal Ilmiah STIKes Kendal. 2020; 10 (2): 251-256.

25. Mohammad A, Madanijah S. Konsumsi buah dan sayur anak usia sekolah dasar di Bogor. Jurnal Gizi Pangan. 2015;10(1): 71-76.

26. Saputra MD, Wahyuni Y, Nuzrina R. Pengaruh pemberian edukasi gizi melalui media video dan leaflet terhadap perubahan konsumsi buah dan sayur pada siswa SMP Al Chasanah Tahun 2016. Jakarta: FIK Universitas Esa Unggul. Disertasi. 2016.

27. Asyary MS, Moviana Y, Surmita. Penyuluhan gizi dengan pengembangan food model 'piring makananku' meningkatkan perilaku konsumsi makanan seimbang pada remaja. Jurnal Riset Kesehatan Poltekkes Depkes RI Bandung. 2018;10(1): 1-8. 